\title{
Teaching NeuroImages: Multimodality imaging of carotid web
}

Dimitri Renard, MD, Jennifer Hampton, MD, Mariam Keita, MD, and Cornelia Freitag, MD

Neurology ${ }^{\circledR}$ 2018;90:e1541. doi:10.1212/WNL.0000000000005359
Correspondence

Dr. Renard

dimitrirenard@hotmail.com

Figure Doppler ultrasound, CT, and magnetic resonance (MR) angiography
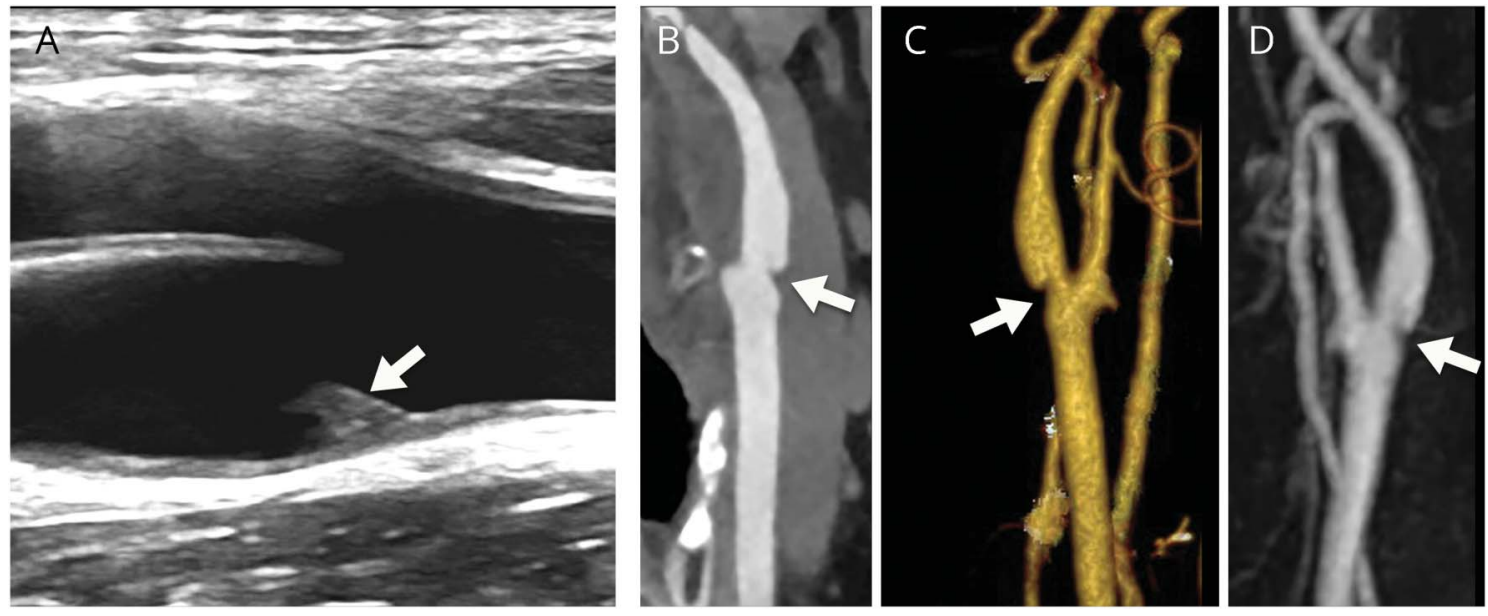

Doppler ultrasound (A), CT angiography (B, maximum intensity projection; C, 3D), and 3D contrast-enhanced MR angiography (D) showing the carotid web.

A 52-year-old woman without cardiovascular risk factors presented with an acute middle cerebral artery infarction. An ipsilateral thin, smooth, membrane-like intraluminal filling defect along the posterior wall of the internal carotid bulb compatible with carotid web (CW) was observed on Doppler ultrasound, CT, and magnetic resonance angiography (figure). No other abnormalities were found on extensive diagnostic workup. CW is thought to represent an intimal variant of fibromuscular dysplasia. ${ }^{1,2}$ Although data are scarce, CW may be associated with increased stroke risk in young patients with cryptogenic anterior circulation infarction and with a high risk of stroke recurrence. ${ }^{2}$

\section{Author contributions}

Dimitri Renard: drafting/revising the manuscript, study concept or design, analysis or interpretation of data. Jennifer Hampton: analysis or interpretation of data. Mariam Keita: analysis or interpretation of data. Cornelia Freitag: analysis or interpretation of data.

\section{Study funding}

No targeted funding reported.

\section{Disclosure}

The authors report no disclosures relevant to the manuscript. Go to Neurology.org/ $\mathrm{N}$ for full disclosures.

\section{References}

1. Coutinho JM, Derkatch S, Potvin AR, et al. Carotid artery web and ischemic stroke: a case-control study. Neurology 2017;88:65-69.

2. Haussen DC, Grossberg JA, Bouslama M, et al. Carotid web (intimal fibromuscular dysplasia) has high stroke recurrence risk and is amenable to stenting. Stroke 2017;48:3134-3137. 


\section{Neurology}

\section{Teaching NeuroImages: Multimodality imaging of carotid web \\ Dimitri Renard, Jennifer Hampton, Mariam Keita, et al. \\ Neurology 2018;90; 1541 \\ DOI 10.1212/WNL.0000000000005359}

\section{This information is current as of April 23, 2018}

\section{Updated Information \& Services}

References

Citations

Subspecialty Collections

Permissions \& Licensing

Reprints including high resolution figures, can be found at: http://n.neurology.org/content/90/17/e1541.full

This article cites 2 articles, 2 of which you can access for free at: http://n.neurology.org/content/90/17/e1541.full\#ref-list-1

This article has been cited by 1 HighWire-hosted articles: http://n.neurology.org/content/90/17/e1541.full\#\#otherarticles

This article, along with others on similar topics, appears in the following collection(s):

\section{All Imaging}

http://n.neurology.org/cgi/collection/all_imaging

CT

http://n.neurology.org/cgi/collection/ct

Infarction

http://n.neurology.org/cgi/collection/infarction MRI

http://n.neurology.org/cgi/collection/mri

Stroke in young adults

http://n.neurology.org/cgi/collection/stroke_in_young_adults

Information about reproducing this article in parts (figures,tables) or in its entirety can be found online at:

http://www.neurology.org/about/about_the_journal\#permissions

Information about ordering reprints can be found online:

http://n.neurology.org/subscribers/advertise

Neurology ${ }^{\circledR}$ is the official journal of the American Academy of Neurology. Published continuously since 1951 , it is now a weekly with 48 issues per year. Copyright @ 2018 American Academy of Neurology. All rights reserved. Print ISSN: 0028-3878. Online ISSN: 1526-632X.

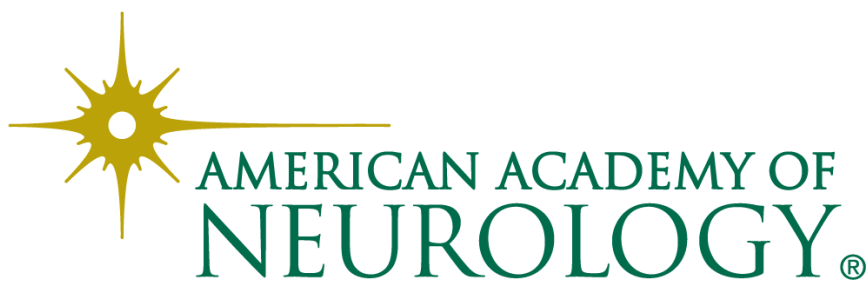

